\title{
INFLUENCE MOTIVATION, ABILITY, AND DISCIPLINE ON PERFORMACE EMPLOYEE DEPARTMENT SALES DAN MARKETING PT PIONIRBETON INDUSTRY JAKARTA
}

\author{
Okiy Hartato \\ PT Pionirbeton Industry Jakarta \\ Email: oqqnii@yahoo.co.id
}

\begin{abstract}
The purpose of the research are to: 1) Test empirically influence of working motivation on performance employee, 2) Test empirically influence of working ability on performance employee, 3) Test empirically influence of working discipline on performance employee, 4) Test empirically influence of working motivation, ability, discipline on performance employee. This study used multiple regression analysis. The research was conducted in Sales and Marketing Department of PT Pionirbeton Industry with population of 43 workers, while the data collecting technique used questionnaire and SPSS version 20.0 for data processing. The result show a significant influence of working motivation on performance employee, working ability on performance employee, working discipline on performance employee. Working motivation, working ability, and working discipline on performance employee, The study found that a of the performance employee as dependent variable is influenced by motivation, ability, and discipline.
\end{abstract}

Keywords: working motivation, working ability, working discipline, performance employee. 


\section{PENDAHULUAN}

Salah satu program untuk mewujudkan kesejahteraan adalah peningkatan kualitas sumber daya manusia, karena sumber daya manusia merupakan asset yang potensial dan strategis dalam menjalankan roda organisasi yang pada akhirnya akan mendukung tujuan organisasi. Untuk meningkatkan kinerja karyawan dan perbaikan efisiensi organisasi, manajemen sumber daya manusia selalu memegang peranan penting berperan aktif dan dominan dalam setiap kegiatan perusahaan. Tingkat kinerja pegawai yang tinggi akan dapat memperkuat perusahaan yang akhirnya dapat meningkatkan keuntungan bagi perusahaan.

Untuk mengatasi hal tersebut diperlukan tenaga-tenaga profesional yang memiliki kemampuan, ketrampilan, konseptual, yang bertanggung jawab serta mengerti akan tujuan perusahaan. Setiap karyawan harus mampu bekerjasama dengan memberikan dorongan dan bekerja keras dalam menjalankan tugas pekerjaannya. Untuk melaksanakan aktivitas organisasi dalam pencapaian tujuan, maka motivasi individu kepada individu lain atau kelompok tim kerja sesuai pada situasi dan kondisi tertentu.

Perubahan lingkungan bisnis ready mix concrete yang cepat ditandai dengan banyaknya pertumbuhan bisnis ready mix concrete dimana-mana, kemajuan perubahan teknologi dan informasi, perubahan selera pasar, perubahan ekonomi, perubahan demografi, kondisi ini menuntut perubahan dan pengembangan individu dalam organisasi perusahaan.

Dalam persaingan yang sangat ketat agar menjadi lebih unggul, perusahaan harus memiliki kinerja yang baik. Semua itu tergantung oleh para individu sebagai pengambil keputusan dalam setiap kegiatan kerja. Untuk mencapai kinerja yang baik perusahaan harus dapat memanfaatkan sumber daya manusia yang ada di dalamnya termasuk memaksimalkan fungsi sumber daya manusia.

PT Pionirbeton Industri didirikan sebagai perusahaan ready mix concrete di Jakarta pada tahun 2002, yang sebelumnya adalah PT Indomix. Momentum ini merupakan awal baru bagi perusahaan bisnis secara fundamental. Seiring dengan perubahan manajemen dan sebagai perwujudan dari komitmen, perusahaan telah 
melakukan proses strategic review yang berdasarkan pada potensi pasar dan kemampuan kompetitif PT Pionirbeton Industri. Banyak perubahan yang telah dialami oleh PT Pionirbeton Industri setelah kepemilikan tahun 2002 dikuasai oleh konsorsium asing Heidelbergcement Group.

Seiring perubahan kepemilikan dan adanya persaingan bisnis yang semakin ketat, di sektor ready mix concrete melahirkan perubahan yang fundamental pada strategi bisnis yang berimbas pada perubahan strategi keuangan, strategi pemasaran, strategi pelayanan, strategi proyek, dan strategi sumber daya manusia. Berikut ini adalah beberapa batching plant pada tahun 2012 di wilayah: DKI Jakarta, Propinsi Banten, Propinsi Jawa Barat, Propinsi Jawa Tengah, DI Yogyakarta, Propinsi Jawa Timur, dan Propinsi Bali. Perusahaan akan terus mengembangkan bisnis ke wilayah Propinsi Sumatera, Propinsi Irian Jaya, Propinsi Kalimantan.

PT Pionirbeton Industri yang merupakan salah satu pengelola ready mix concrete menyadari bahwa untuk dapat memenangkan persaingan harus memiliki kinerja yang tinggi, baik kinerja individu atau kinerja tim. Perusahaan terus mengembangkan sumber daya manusia untuk bersaing dalam industri ready mix concrete dan mengerjakan proyek-proyek besar. Penelitian ini bertujuan untuk mengetahui: 1) deskripsi tentang motivasi, kemampuan, disiplin, serta kinerja, 2) menguji secara empiris pengaruh motivasi, kemampuan, disiplin terhadap kinerja karyawan Departemen Sales dan Marketing PT Pionirbeton Industri baik secara parsial dan simultan.

\section{KAJIAN TEORETIK}

\section{Kinerja}

Dijelaskan menurut (Aguinis, 2013:2) "performance management is a continous process of identifiying, measuring, and developing the performance of individuals and teams and aligning performance with the strategic goals of the organization", menyatakan bahwa manajemen kinerja merupakan proses yang berkesinambungan melalui identifikasi, pengukuran, dan pembangunan kinerja individu ataupun kelompok. Terdapat dua komponen yaitu: (continous process), 
proses yang berkesinambungan dan (alignment with strategic goals) menyelaraskan pencapaian target yang telah ditetapkan.

Menurut (Robbins, 2010:188) kinerja adalah hasil akhir dari sebuah aktivitas. Aktivitas tersebut dengan melaksanakan kewajiban kerja seefisien dan seefektif mungkin, kinerja adalah apa yang dihasilkan dari aktivitas tersebut.

\section{Motivasi}

(Robbins, 2010:109) motivasi mengacu pada proses dimana usaha seseorang diberi energi, diarahkan, dan berkelanjutan menuju tercapainya suatu tujuan. Definisi ini memiliki tiga elemen kunci: energi, arah, dan ketekunan. Elemen energi adalah ukuran dari intensitas atau dorongan. Seseorang yang termotivasi menunjukkan usaha dan bekerja keras. Namun, kualitas usaha itu juga harus dipertimbangkan. Usaha tingat tinggi tidak selalu mengarah pada kinerja pekerjaan yang menguntungkan kecuali usaha tersebut disalurkan ke arah yang menguntungkan organisasi. Usaha yang diarahkan, dan konsisten dengan tujuan organisasi adalah jenis usaha yang perusahaan inginkan dari para karyawan. Akhirnya, motivasi mencakup dimensi ketekunan.

Perusahaan menginginkan karyawan untuk tekun dalam usahanya untuk mencapai tujuan tersebut. Menurut (Robbins, 2010:117) menyebutkan bahwa perilaku adalah fungsi dari konsekuensi-konsekuensinya. Konsekuensi yang segera mengikuti perilaku dan meningkatkan probabilitas dimana perilaku akan diulang disebut daya penguat (reinforces).Menurut (B.F Skinner dalam Robbins dan Coulter, 2010:117) menyebutkan orang akan cenderung terlibat dalam perilaku yang diinginkan jika karyawan diberi imbalan untuk melakukannya. Penghargaan ini paling efektif jika diberikan setelah perilaku yang diinginkan; sehingga perilaku yang tidak dihargai atau yang dihukum tidak akan diulang.

\section{Kemampuan}

Menurut (Robbins, 2010:52) menyatakan kemampuan untuk mengenali dan mengelola isyarat dan informasi emosi, terdiri dari: kesadaran diri adalah kemampuan untuk menyadari apa yang Anda rasakan. Pengelolaan diri adalah 
kemampuan untuk mengelola emosi dan impuls Anda sendiri. Motivasi diri adalah kemampuan untuk tetap tegar dalam menghadapi kemunduran dan kegagalan. Empati adalah kemampuan untuk merasakan apa yang dirasakan orang lain. Kemampuan sosial adalah kemampuan untuk menangani emosi orang lain.

Menurut (Yukl, 2010:43) ada tiga definisi terkait dengan kemampuan melakukan fungsi manajerial, yaitu: kemampuan teknis (technical skills) yaitu kemampuan mencakup pengertian suatu aktifitas khusus dan kecakapan, terkait dengan peralatan dan perlengkapan terutama yang menyangkut metode, proses, prosedur dan teknik. Kemampuan perilaku atau hubungan kemanusiaan, yaitu kemampuan untuk berhubungan dengan orang lain, perasaan, sikap, dan motif (bisa berbentuk empati dan sensitif sosial).

Kemampuan komunikasi memimpin membangkitkan semangat dan menyelesaikan konflik dengan baik. Kemampuan efektif dan bekerjasama dalam menjalin hubungan (diplomasi, kemampuan berbicara, pengetahuan dan lingkungan sosial).

Kemampuan konseptual yaitu kemampuan analisa, berpikir logika, untuk melihat organisasi sebagai keseluruhan, mencakup fungsi-fungsi organisasi yang saling bergantung, kemampuan mevisualisasi hari depan, visi organisasi, menyelesaikan masalah, mengatisipasi perubahan, menghargai kesempatan, dan masalah potensial (mempertimbangkan induktif dan deduktif)

\section{Disiplin}

Penelitian lainnya menurut (Dessler, 2005:607) mengatakan bahwa tujuan utama pendisiplinan adalah mendorong pegawai berperilaku sepantasnya ditempat kerja dimana perilaku yang pantas ditetapkan sebagai kepatuhan terhadap peraturan dan prosedur. Dalam sebuah organisasi pada dasarnya peraturan perusahaan berfungsi sama dengan perundang-undangan dan tindakan pendisiplinan timbul sebagai akibat adanya pelanggaran peraturan.

Menurut pendapat (Mello, 2011:8) menyatakan kebijakan Human Resources memasukkan sikap disiplin karyawan sebagai motivasi penguatan positif terhadap kesalahan, peringatan, terkait dengan gaji, penurunan pangkat, pemberian 
hukuman, dan pemecatan. HR memberikan perubahan sebagai keadilan dari cermin bersikap disiplin menjamin seseorang agar bisa memberikan rasa hormat.

Menurut (Dessler, 2011:543) Bahwa suatu proses pendisiplinan yang pantas dan adil (basics of a fair and just disciplinary process) didasarkan atas persyaratan berikut: Kebiasaan dan peraturan (rules and regulations) Perlu diadakan suatu proses banding sebagai proses pendisiplinan. Hal ini membantu menjamin bahwa tindakan pendisiplinan dilakukan secara adil. Hukuman progresif (progressive penalties) Pendisiplinan efektif adalah sistem hukuman progresif, yang mana hukuman dimulai dari peringatan lisan, peringatan tertulis, skorsing sampai pembebasan tugas.

Perlu diadakan suatu proses banding sebagai proses pendisiplinan (formal disciplinary appeals processes) Peraturan yang jelas, peraturan ini mengatur soal pencurian, perusakan milik kantor, minuman keras pada waktu melaksanakan pekerjaan dan tidak disiplin. Tujuannya adalah untuk memberitahu karyawan tentang hal yang boleh dan tidak boleh.

Menurut (Aguinis, 2013:247) menyatakan bahwa proses pendisiplinan terhadap karyawan tidak datang secara tiba-tiba, jika menginginkan manajemen kinerja yang baik didalam organisasi maka kesempatan untuk mengatasi masalah kinerja karyawan bersama atasan mau membantu dan menunjukkan umpan balik.

\section{METODE PENELITIAN}

Pendekatan penelitian yang digunakan adalah pendekatan positivism. Pendekatan ini memandang ilmu sebagai metode-metode yang terorganisasi dalam mengkombinasikan logika deduktif (bertujuan menjelaskan fakta) dengan observasi empiris, dan perilaku individual untuk menemukan serta memastikan kebenaran seperangkat hukum sebab akibat untuk memprediksi pola umum kegiatan-kegiatan manusia.

Menurut (Render dan Stair, 2000:2) metode kuantitatif adalah pendekatan ilmiah terhadap pengambilan keputusan manajerial dan ekonomi. Oleh karena itu, pendekatan positivism merupakan pendekatan kuantitatif. Alasan digunakan pendekatan kuantitatif dalam penelitian ini adalah sebagai berikut: a) Mempunyai 
kebenaran objektif atau kebenaran ilmiah b) Mempunyai ketepatan deskripsi suatu variable c) Mempunyai daya generalisasi yang baik.

Penjelasan lain menurut (Malhotra, 2005:90) penelitian riset konklusif terdiri dari; menguji hipotesis dan menguji hubungan, informasi yang dibutuhkan didefinisikan dengan jelas, proses riset formal terstruktur, sampel besar dan mewakili, analisis data secara kuantitatif, kesimpulan, temuan digunakan sebagai masukan bagi pembuat keputusan manajemen. Selanjutnya yang dilakukan dalam riset deskriptif adalah satu jenis riset konklusif yang mempunyai tujuan utama menguraikan sesuatu biasanya karateristik. Karakteristik ditandai dengan formulasi hipotesis spesifik, rancangan direncanakan dan terstruktur. Metode yang dipakai adalah data sekunder, survey, panel, dan observasi. Pengumpulan data untuk penelitian ini dilakukan dengan mengumpulkan data sebanyak-banyaknya menggunakan teknik non tes, yaitu: kuisioner (angket).

Dalam pengumpulan data variabel Peneliti menggunakan angket tertutup dalam bentuk skala Likert. Populasi dalam penelitian ini adalah karyawan PT Pionirbeton Industri, Departemen Sales dan Marketing berjumlah 43 orang karyawan. Mengingat populasi terjangkau dalam penelitian ini menggunakan seluruh populasi dan peneliti tidak menggunakan metode sampel, mengingat keterbatasan tenaga kerja maka dalam penelitian ini ditetapkan sebanyak keseluruhan yaitu 43 orang.

Dalam penjelasan (Masyhudzulhak, 2012:53) validitas adalah alat ukur untuk mengukur item-item pertanyaan dari variabel, penelitian yang benar dan akurat. Uji validitas ini dilakukan untuk menunjukkan sejauh mana ketepatan dan kecermatan suatu alat ukur dalam melakukan fungsi ukurnya. Uji validitas pada penelitian ini menggunakan product moment pearson.

Uji normalitas berguna untuk mengetahui apakah variabel dependen, variabel independen atau keduanya berdistribusi normal atau mendekati normal atau tidak. Apabila data ternyata data tidak berdistribusi normal, maka analisis nonparametrik dapat digunakan. Jika data berdistribusi normal, maka analisis parametrik termasuk model-model regresi dapat digunakan. Untuk mendeteksinya dapat diketahui melalui penyebaran data pada grafik dan uji kologorov-smirnov (Sekaran, 2009:291). 
Uji multikolinearitas berguna untuk mengetahui apakah pada model regresi yang diajukan telah ditemukan korelasi kuat antarvariabel bebas menurut (Sekaran, 2009:353). Hal ini dapat diketahui dari besaran VIF (Variance Inflation Factor), dimana jika hasil VIF mendekati angka 1 berarti tidak terjadi multikolinearitas.

Uji heteroskedastisitas dilakukan untuk mengetahui apakah dalam sebuah regresi terjadi ketidaksamaan varians dari residual suatu pengamatan ke pengamatan lain.

Secara spesifik, analisis regresi berganda digunakan untuk menguji hubungan dan sejauh mana pengaruh variabel independen terhadap variabel dependen. Persamaan regresi berganda digambarkan sebagai berikut:

$$
\mathrm{Y}=\alpha+\beta_{1} \mathrm{X}_{1}+\beta_{2} \mathrm{X}_{2}+\beta_{3} \mathrm{X}_{3}+\varepsilon
$$

Dimana:

- $\mathrm{Y}=$ Variabel dependen atau terikat

- $\alpha=$ konstanta (intercept)

- $\beta_{0}-\beta_{\mathrm{k}}=$ koefisien regresi

- $\mathrm{X}_{1}-\mathrm{X}_{\mathrm{k}}=$ variabel independent atau bebas

- $\varepsilon=$ error

\section{HASIL DAN PEMBAHASAN}

Pada bagian ini dapat dilihat sejumlah penemuan penting dalam penelitian. Data yang telah terkumpul dianalisis validitas dan reabilitasnya. Selanjutnya dilakukan uji hipotesis dengan analisis regresi berganda untuk menjawab pertanyaan-pertanyaan penelitian yang diajukan pada penelitian.

\section{Uji Validitas}

Uji validitas merupakan salah satu teknik untuk menguji sejauh mana item pernyataan kuesioner valid. Pernyataan yang valid yaitu pernyataan yang satu dengan yang lain saling mendukung. Pada penelitian ini, telah dilakukan uji validitas terhadap 30 orang responden. Uji Validitas variabel Kinerja berdasarkan tabel lampiran Uji Validitas variabel Kinerja diketahui bahwa dari 15 butir pernyataan yang digunakan untuk mengukur variabel kinerja karyawan setelah mengalami uji validitas ternyata pernyataan butir 1,2,10 tidak 
valid. Selanjutnya, butir no.1,2,10 ini dihapus dan tidak digunakan dalam uji hipotesis. Uji Validitas variabel motivasi diketahui bahwa dari 9 butir peryataan yang digunakan untuk mengukur variabel motivasi karyawan setelah mengalami uji validitas ternyata pernyataan butir 17 tidak valid. Selanjutnya, butir no.17 ini dihapus dan tidak digunakan dalam uji hipotesis.

Uji Validitas Variabel kemampuan kerja diketahui bahwa dari 9 butir pertanyaan yang digunakan untuk mengukur variabel kemampuan kerja karyawan setelah mengalami uji validitas ternyata pernyataan 33 tidak valid. Selanjutnya, butir no.33 ini dihapus dan tidak digunakan dalam uji hipotesis. Uji Validitas variabel Disiplin memiliki 12 butir pernyataan setelah mengalami uji validitas ternyata semua pernyataan valid secara statistik.

\section{Uji Reliabilitas}

Maka perlu diuji reliabilitas dari setiap variabel yang digunakan dengan melihat Cronbach's coefficient alpha sebagai koefisien dari reliabilitas. Menurut (Sekaran, 2009:312) Cronbach's coefficient alpha yang cukup diterima (acceptable) adalah yang bernilai antara 0,60 sampai 0,70 atau lebih.

Tabel 1

Hasil Pengujian Reliabilitas

\begin{tabular}{ccc}
\hline Variabel & Alpha & Keputusan \\
\hline Kinerja & 0,685 & Realibel \\
Motivasi & 0,630 & Realibel \\
Kemampuan & 0,632 & Realibel \\
Disiplin & 0,722 & Realibel \\
\hline
\end{tabular}

Sumber: data kuesioner diolah oleh peneliti dengan SPSS 20

\section{Uji Normalitas}

Tujuan dari uji normalitas adalah untuk menguji apakah dalam sebuah model regresi, variabel terikat dan variabel bebas mempunyai distribusi data normal atau mendekati normal. Berikut adalah uji Normalitas dengan menggunakan Grafik Normal Probability Plot. Grafik Normal Probability menunjukkan bahwa sebaran data rapat dan berada di sekitar garis diagonal. Hal ini mencerminkan bahwa data yang digunakan telah memenuhi uji normalitas. 


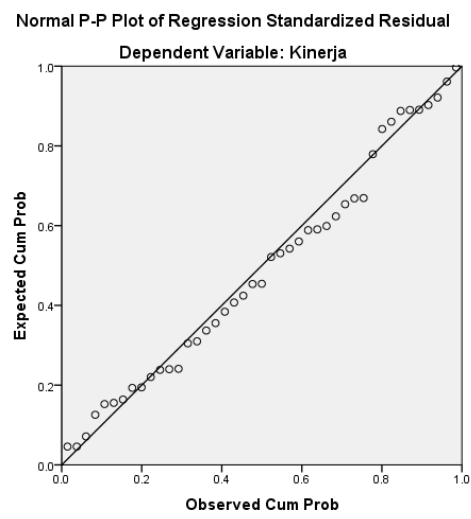

Gambar 4.1

Grafik Normal Probability Plot Sumber: Data SPSS 20 diolah Peneliti

\section{Uji Multikolinearitas}

Uji Multikolinieritas bertujuan untuk menguji apakah dalam model regresi yang terbentuk ada korelasi yang tinggi atau sempurna diantara variabel bebas atau tidak. Jika dalam model regresi yang terbentuk terdapat korelasi yang tinggi atau sempurna diantara variabel bebas maka model regresi terbentuk dinyatakan mengandung gejala multikolinieritas.

Tabel 2

Uji Multikolineraritas dengan TOL dan VIF

\begin{tabular}{|rl|r|r|}
\hline \multirow{2}{*}{ Model } & \multicolumn{2}{|c|}{ Collinearity Statistics } \\
\cline { 3 - 4 } & & \multicolumn{1}{|c|}{ Tolerance } & \multicolumn{1}{c|}{ VIF } \\
\hline \multirow{4}{*}{1} & (Constant) & & \\
& Motivasi & .937 & 1.067 \\
& Kemampuan & .556 & 1.800 \\
& Disiplin & .542 & 1.846 \\
\hline
\end{tabular}

Sumber: Data SPSS 20 diolah Peneliti, 2013

Dari tabel 4.3 terlihat bahwa VIF (Variance Infloating Factor) variabel Motivasi, Kemampuan, Disiplin lebih kecil dari 10, maka artinya data yang digunakan bebas dari gejala multikolinearitas dan pada model regresi yang terbentuk tidak terjadi gejala multikolinieritas. 


\section{Uji Heteroskedastisitas}

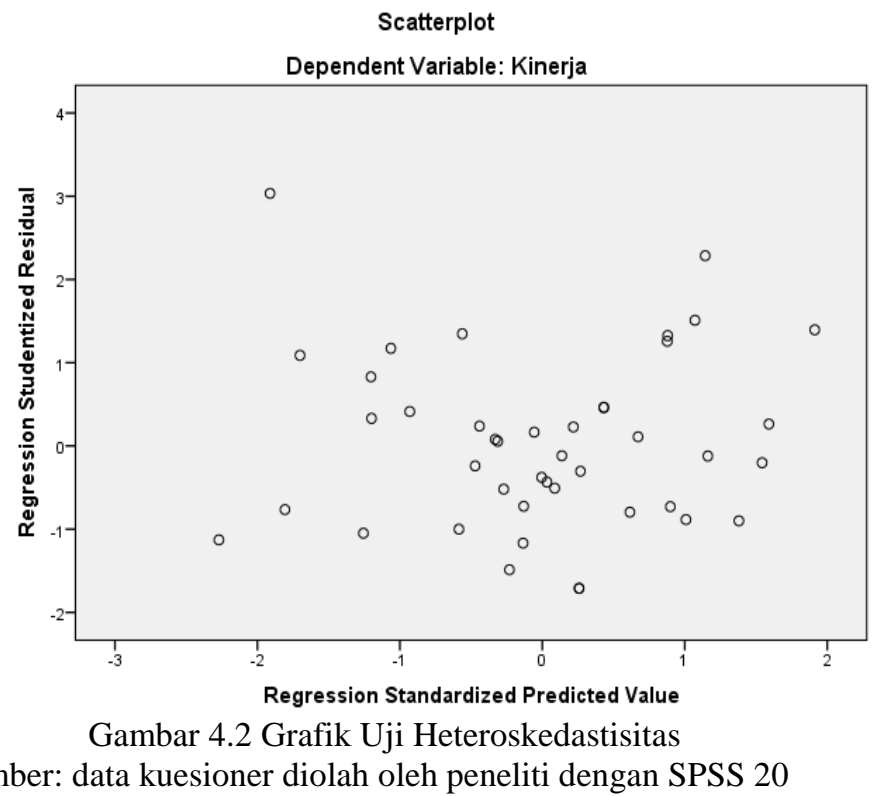

Berikut adalah Uji Heteroskedastisitas dengan metoda Analisis Grafik dari gambar 4.2 terlihat bahwa titik titik menyebar secara acak (random) baik diatas maupun dibawah angka 0 sumbu $\mathrm{Y}$ dan tidak membentuk suatu pola tertentu yang jelas, serta tersebar secara merata. Hal ini menunjukan bahwa tidak terjadi heteroskedastisitas pada model regresi sehingga model regresi layak dipakai

\section{PENGUJIAN HIPOTESIS}

\section{Uji t}

Uji t digunakan untuk mengetahui apakah variabel independen secara parsial berpengaruh atau tidak terhadap variabel dependen. Jika nilai Sig t hitung $\leq \alpha=0.05$ maka Ha diterima dan H0 ditolak artinya bahwa suatu variabel independen secara parsial mempengaruhi variabel dependen. Hasil uji t dapat dilihat dari hasil output SPPS sebagai berikut: 
Tabel 3

Hasil Uji t

\begin{tabular}{|c|c|c|c|c|c|c|}
\hline \multirow{2}{*}{\multicolumn{2}{|c|}{ Model }} & \multicolumn{2}{|c|}{$\begin{array}{c}\text { Unstandardized } \\
\text { Coefficients }\end{array}$} & \multirow{3}{*}{$\begin{array}{c}\text { Standardized } \\
\text { Coefficients } \\
\text { Beta }\end{array}$} & \multirow[t]{2}{*}{$\mathrm{T}$} & \multirow[t]{2}{*}{ Sig. } \\
\hline & & B & Std. Error & & & \\
\hline 1 & (Constant) & .876 & .380 & & 2.306 & .027 \\
\hline & Motivasi & .266 & .070 & .360 & 3.786 & .001 \\
\hline & Kemampuan & .257 & .101 & .314 & 2.542 & 015 \\
\hline & Disiplin & .333 & .104 & .400 & 3.202 & .003 \\
\hline
\end{tabular}

Sumber: data kuesioner diolah oleh peneliti dengan SPSS 20

Hipotesis pertama $\left(\mathrm{H}_{1}\right)$ : Menguji Pengaruh Motivasi $\left(\mathrm{X}_{1}\right)$ terhadap Kinerja. Dari tabel 3. terlihat bahwa nilai Sig. $t_{\text {hitung }}$ untuk variabel Motivasi sebesar $0,001<\alpha=$ 0,05 maka Ha diterima dan $\mathrm{H} 0$ ditolak. Artinya bahwa variabel $\mathrm{X}_{1}$ secara parsial memiliki pengaruh terhadap Y. Nilai t positif menunjukan bahwa variabel $\mathrm{X}_{1}$ memiliki hubungan yang searah dengan Y. Motivasi memiliki pengaruh positif dan signifikan terhadap Kinerja.

Hipotesis kedua $\left(\mathrm{H}_{2}\right)$ : Menguji Pengaruh Kemampuan $\left(\mathrm{X}_{2}\right)$ terhadap Kinerja Kerja (Y). Dari tabel 4.3 terlihat bahwa nilai Sig. $t_{\text {hitung }}$ untuk variabel Kemampuan sebesar 0,015> $\alpha=0,05$ maka Ha diterima dan H0 ditolak. Artinya bahwa variabel $\mathrm{X}_{2}$ secara parsial mempengaruhi Y. Nilai t positif menunjukan bahwa variabel memiliki hubungan yang searah dengan Y. Jadi dapat disimpulkan bahwa Kemampuan memiliki pengaruh positif dan signifikan terhadap Kinerja.

Hipotesis ketiga $\left(\mathrm{H}_{3}\right)$ : Menguji Pengaruh Disiplin $\left(\mathrm{X}_{3}\right)$ terhadap Kinerja Kerja (Y). Dari tabel 4.3 terlihat bahwa nilai Sig. $t_{\text {hitung }}$ untuk variabel Disiplin sebesar $0,003>\alpha=0,05$ maka Ha diterima dan $\mathrm{H} 0$ ditolak. Artinya bahwa variabel $\mathrm{X}_{3}$ secara parsial mempengaruhi $Y$. Nilai t positif menunjukan bahwa variabel memiliki hubungan yang searah dengan Y. Jadi dapat disimpulkan bahwa Disiplin memiliki pengaruh positif dan signifikan terhadap Kinerja.

\section{Uji-F}

Uji F digunakan untuk mengetahui apakah variabel-variabel independen secara simultan berpengaruh terhadap variabel dependen. Jika nilai Sig $\mathrm{F}_{\text {hitung }} \leq \alpha$ $=0.05$ maka Ha diterima dan Ho ditolak, artinya bahwa semua variabel 
indepeden secara simultan berpengaruh signifikan terhadap variabel dependen. Untuk analisis uji F dapat digunakan hasil ouput SPSS dari tabel Anova sebagai berikut:

Tabel 4

Pengujian secara simultan $\mathrm{X}_{1}, \mathrm{X}_{2}, \mathrm{X}_{3}$, terhadap $\mathrm{Y}$

\begin{tabular}{|c|c|c|c|c|c|}
\hline \multicolumn{6}{|c|}{ ANOVA $^{\mathrm{a}}$} \\
\hline Model & Sum of Squares & Df & Mean Square & $\mathrm{F}$ & Sig. \\
\hline 1 Regression & 2.505 & 3 & .835 & 26.420 & $.000^{\mathrm{b}}$ \\
\hline Residual & 1.233 & 39 & .032 & & \\
\hline Total & 3.738 & 42 & & & \\
\hline $\begin{array}{l}\text { a. Dependent Va } \\
\text { b. Predictors: (C) }\end{array}$ & $\begin{array}{l}\text { e: Kinerja } \\
\text { nt), Disiplin, Mot }\end{array}$ & i, Ken & uan & & \\
\hline
\end{tabular}

Sumber: data kuesioner diolah oleh peneliti dengan SPSS 20

- Hipotesis keempat $\left(\mathrm{H}_{4}\right)$ : Menguji Pengaruh Motivasi, Kemampuan, Disiplin, $\left(\mathrm{X}_{1}, \mathrm{X}_{2}, \mathrm{X}_{3}\right)$ terhadap Kinerja Kerja (Y). Dari tabel 4.5 dapat dilihat bahwa nilai $F_{\text {hitung }}$ sebesar 26,420 dengan nilai probabilitas (Sig.) = 0,000 Nilai (Sig.) lebih kecil dari 0,05 mencerminkan Ha diterima dan H0 ditolak. Dapat disimpulkan bahwa variabel Motivasi, Kemampuan, Disiplin, secara bersama-sama berpengaruh signifikan terhadap Kinerja.

\section{Koefisien Determinasi $\left(\mathbf{H}_{4}\right)$ :}

Koefisien determinasi akan menjelaskan seberapa besar perubahan atau variasi suatu variabel bisa dijelaskan oleh perubahan atau variasi pada variabel yang lain. Nilai koefisien bernilai antara 0 dan 1, jika hasil mendekati angka 0 berarti kemampuan variabel-variabel independen dalam menjelaskan variasi variabel amat terbatas. Tapi jika hasil mendekati angka 1 berarti variabel-variabel independen memberikan hampir semua informasi yang dibutuhkan untuk memprediksi variasi variabel dependen. Untuk analisis lebih lanjut dapat dilihat pada tabel berikut ini:

Tabel 5 Koefisien Determinasi

\begin{tabular}{lcccc}
\hline & \multicolumn{3}{c}{ Model Summary } \\
Model & $\mathrm{R}$ & R Square & $\begin{array}{c}\text { Adjusted R } \\
\text { Square }\end{array}$ & $\begin{array}{c}\text { Std. Error of the } \\
\text { Estimate }\end{array}$ \\
1 & $\begin{array}{c}.819^{\mathrm{a}} \\
\text { a. Predictors: (Constant), Disiplin, Motivasi, Kemampuan }\end{array}$ & .17780 \\
b. Dependent Variable: Kinerja & .670 & Square & \\
\hline
\end{tabular}

Sumber: data kuesioner diolah oleh peneliti dengan SPSS 20 
Dari tabel 5 dapat disimpulkan bahwa frekuensi keikutsertaan variabel Motivasi, Kemampuan, dan Disiplin berpengaruh sebesar 64,5\% terhadap Kinerja, sedangkan 35,5\% Kinerja dipengaruhi oleh variabel lain yang tidak diteliti.

$$
\mathrm{Y}=0,876+0,266 \mathrm{X}_{1}+0,257 \mathrm{X}_{2}+0,333 \mathrm{X}_{3}
$$

Dimana :

$\mathrm{Y}=$ Kinerja Karyawan

$\mathrm{X}_{1}=$ Motivasi

$\mathrm{X}_{2}=$ Kemampuan

$\mathrm{X}_{3}=$ Disiplin

Pengertian dari model regresi berganda tersebut adalah:

a. Koefisien regresi $X_{1}$ (Motivasi) sebesar 0,266 menunjukkan pengaruh yang positif antara Motivasi dengan Kinerja Kerja. Namun nilai signifikansi sebesar $0,001<\alpha=0,05$ menunjukkan pengaruh Motivasi yang signifikan terhadap Kinerja.

b. Koefisien regresi $X_{2}$ (Kemampuan) sebesar 0,257 menunjukkan pengaruh yang positif antara Kemampuan dengan Kinerja Kerja. Namun nilai signifikansi sebesar $0,015>\alpha=0,05$ menunjukkan pengaruh Kemampuan yang signifikan terhadap Kinerja.

c. Koefisien regresi $X_{3}$ (Disiplin) sebesar 0,333 menunjukkan pengaruh yang positif antara Disiplin dengan Kinerja Kerja. Namun nilai signifikansi sebesar $0,003<\alpha=0,05$ menunjukkan pengaruh Disiplin yang signifikan terhadap Kinerja.

d. Hasil Koefisien Determinasi menunjukkan Motivasi, Kemampuan kerja, Disiplin kerja berpengaruh sebesar 64,5\% terhadap Kinerja, sedangkan $35,5 \%$ Kinerja dipengaruhi oleh variabel lain yang tidak diteliti.

\section{KESIMPULAN DAN SARAN}

Berdasarkan hasil penelitian, temuan data, tabulasi, pengolahan, pengkajian dan analisis seluruh data-data yang terjaring melalui instrumen tiap variabel, maka kesimpulan dari penelitian ini adalah dapat diuraikan sebagai berikut:

1. Terdapat pengaruh langsung positif motivasi terhadap kinerja. Hal ini berarti bahwa peningkatan kinerja dapat dilakukan dengan meningkatkan motivasi.. 
2. Terdapat pengaruh langsung positif kemampuan kerja terhadap kinerja. Hal ini berarti bahwa peningkatan kinerja dapat dilakukan dengan meningkatkan kemampuan kerja.

3. Terdapat pengaruh langsung positif disiplin terhadap kinerja. Hal ini berarti bahwa peningkatan kinerja dapat dilakukan dengan meningkatkan disiplin kerja.

4. Berarti variabel motivasi, kemampuan kerja, disiplin kerja mempunyai hubungan yang positif dengan kinerja karyawan. Artinya, jika motivasi, kemampuan kerja dan disiplin kerja ditingkatkan maka kinerja karyawan juga akan mengalami peningkatan.

5. Variabel atau faktor lain seperti: tidak ada material agregat, pasir, terlambatnya supply material, kerusakan mesin conveyor, tidak adanya Driver Truck Mixer, kerusakan truk mixer, demo tenaga kerja, pindahnya tenaga kerja atau sumber daya manusia ke industri sejenis lainnya, perubahan struktur organisasi dan sistem manajemen.

\section{Saran}

Tidak dipungkiri bahwa penelitian ini juga memiliki keterbatasan kajian. Karenanya, perlu dikemukakan beberapa hal untuk perbaikan pada penelitian mendatang. Dengan demikian untuk dapat diimplementasikan secara optimal lagi dalam penelitian berikutnya maka dapat disampaikan beberapa saran sebagai berikut: Dalam penelitian ini, pembahasan hanya terbatas pada kinerja individu yang berupa motivasi, kemampuan kerja, disiplin kerja sehingga diharapkan dalam penelitian berikutnya dapat menggunakan faktor-faktor lain seperti dukungan organisasi dan kemampuan manajemen.

Kebijakan dalam rangka pengembangan kinerja karyawan PT Pionirbeton Industri Jakarta perlu lebih ditekankan pada bagaimana motivasi, kemampuan kerja, disiplin kerja dapat ditingkatkan dengan mengadakan pendidikan dan pelatihan bagi karyawan. Hal ini sangat penting mengingat motivasi karyawan yang pengaruhnya signifikan secara statistik dalam analisa regresi linear berganda. 


\section{BUKU}

\section{DAFTAR RUJUKAN}

As'ad, M. 2001. Psikologi Industri: Seri Sumber Daya Manusia. Yogyakarta: Liberty.

Aguinis, Herman., 2013, Performance Management. New Jersey: Pearson.

Altman v Minnesota. 2001. Department of Corrections.,"Progressive Discipline" 251 F.3d 1199 ( $8^{\text {th }}$ Cir $)$

Anderson. et. al, 2010, Multivariate Data Analysis. New Jersey: Pearson.

Bernadin, H, John and Russel. 1993. Human Resources Management. Boston: Richard D. Irwin. Illinois.

Colquitt, Lepine dan Wesson. 2009. Organizational Behavior Improving Performance and Commitment in the Workplace. New York: McGrowHill Companies,Inc

Dessler, Gary. 2005, Human Resources Management, Tenth Edition. Kanada: Pearson. Pearson.

2011. Human Resources Management, Twelfth Edition, Kanada:

Fahmi, Irham. 2012. Manajemen. Bandung: Alfabeta.

F. Herzberg's. 2009. Management. New Jersey: Prentice Hall..

Donelly, James H, Gibson, James L and Ivancevich, John. 1994. Fundamental of Management, Texas: Business Publication.

Gibson, James et al. 2009. Organization Behavior, Structures, and Processes. New York: McGraw-Hill Companies, inc.

Griffin, Ricky W, Ronald J. Ebert. 2004. Business, Seven Edition. New Jersey: Pearson. Pearson.

, Ronald J. Ebert. 2006. Business, Eighth Edition. New Jersey:

Greenwood, Michelle R. 2002. "Ethics and HRM: A Review and Conceptual Analysis." Journal of Business Ethics, Vol.3, no.3 (March). 
Jurnal Riset Manajemen Sains Indonesia (JRMSI) | Vol 7, No. 1, 2016

Handoko, T.H. 2001.Manajemen Personalia dan Sumber Daya Manusia,.Yogyakarta: BPFE.

Harbani Pasolog. 2008. Psikologi. CV. Alfabeta: Bandung.

Harris, Michael. 2000. Human Resource Management," A Practical Approach. Second edition. The Dryden Press..

Hasibuan. 2009. Manajemen Sumber Daya Manusia. Jakarta: Masagung.

Irawan, Prasetia. 1999. Logika dan Prosedur Penelitian. Cetakan 1. Jakarta: STIA LAN RI. 2006.

LAN.

, et.al. 2002. Manajemen Sumber Daya Manusia. Jakarta:STIA-

Kofman F. dan P.M Senge. 1995. Comunities of Commitment: The Heart of Learning Organizations. Eds S.Chawla dan J Renensh. Oregon: Productivity Press.

Kovach, Kenneth A. 1980. “Why Motivational Theories Don't Work,” S.A.M advance Management Journal.

Kuncoro, Mudrajad. 2004. Metode Kuantitatif. Yogyakarta: AMP YKPN.

Luthans, Fred, 1995. Organizational Behavior. Seventh Edition. International Edition. New York: McGraw-Hill Companies. Inc.

Nitisemito.A. 1995. Manajemen Personalia. Jakarta: Ghalia Indonesia

Mangkunegara. Anwar Prabu. 2006. Evaluasi Kinerja Sumber Daya Manusia Perusahaan. Bandung: PT. Refika Aditama.

Mangkunegara, Anwar Prabu. 2002. Manajemen Sumber Daya Manusia Perusahaan. Bandung; PT. Remaja Rosdakarya.

Malhotra, Naresh.K. 2005. Riset Pemasaran Pendekatan Terapan, Edisi Keempat. Penerbit Indeks.

Marquardt. Michael J. 1996. Building the Learning Organization. New York: McGraw-Hill Companies. Inc.

Masyhudzulhak. 2012. Memahami Penulisan Ilmiah dan Metode Penelitian. Bengkulu: LP2S. 
Mathis dan Jackson. 2001. Manajemen Sumber Daya Manusia. Buku 2 Jilid Pertama Salemba Empat Jakarta. 2012.

Mello, Jeffrey. A. 2011. Strategic Management of Human Resources. $3^{\text {rd }}$ edition.

Meyer, J.P., Becker, T. E., \& Vandenberghe, C., 2004., "Employee commitment and motivation: A conceptual Analysis and integrative model" Journal of Applied Psychology.

Nadler, David A. dan Edward E. Lawler III. 1976. "Motivation: A Diagnostic Approach." Harvard Business Review. Februari.

Nawawi, Hadari.2001. Manajemen Sumber Daya Manusia (Untuk Bisnis yang Kompetitif). Yogyakarta: Gadjah Mada University Press

Payaman J. Simanjuntak. 1998. Pengantar Ekonomi Sumber Daya Manusia. Jakarta: LPFE-UI.

Priyatno. D, 2008. Independent Learning SPSS. London: Mediakom.

Purwant, Ngalim. 2003. Psikologi Pendidikan. Bandung: PT Remaja Rosdakarya.

Rao, T V. 1992. Penilaian Prestasi Kerja, Teori dan Praktek. Jakarta: Ikrar Mandiri Abadi.

Rao. Knowledge Management Tools and Techniques. 2004.

Rivai, Veithzal and Mohd. Basri, Ahmad Fauzi. 2005. Performance Apraisal: Sistem yang tepat untuk menilai kerja karyawan dan meningkatkan daya saing perusahaan Jakarta:Raja Grafindo.

Rivai, Veitzhal, 2005. Manajemen Sumber Daya Manusia. untuk perusahaan: dari Teori Praktik. Jakarta: Raja Grafindo.

R. M. Steers. R.T. Mowday, and D.L. Shapiro. 2004. "The Future of Work Motivation Theory," Academy of Management Review, July.

Robbins, Stephen P. Mary Coulter. 2009. Management. New Jersey: Prentice Hall Inc.

Robbins, Stephen P. Mary Coulter. 2010. Manajemen, Edisi Kesepuluh. Jilid 2, Jakarta: Erlangga.

Saydam, Gauzali. 2000. Manajemen Sumber Daya Manusia. Jakarta: Gubug Agung. 
Sedarmayanti. 2007. Manajemen Sumber daya Manusia: Reformasi Birokrasi Kerja. Bandung. Ilham Jaya.

Sedarmayanti. 2000. Manajemen Sumber daya Manusia dan Produktivitas Kerja. Bandung. Ilham Jaya.

Sekaran, Uma dan Roger Bougie. 2009. Research Methods for Business, United Kingdom: Fifth Edition.

Santoso, Singgih. 2012. Panduan Lengkap SPSS 20. Jakarta. Elex Media Komputindo

Senge, P.M. 2000. The Academy as a Learning Community: Contradiction in Terms or Realizable Future. In A.F Lucas and Associates. Leading Academic Change: Essential Roles for Department Chairs.

Senge, P.M. 1994. The Fifth Discipline: The Art and Practice of the Learning Organization. New York: Doubleday.

Sinungan, Muchdarsyah. 2005. Productivity: What and How. New York: Literacy.

Siswanto. 2005. Manajemen Tenaga Kerja Indonesia. Jakarta: Bumi Aksara.

Sastrohadiwiryo, Bejo S. 2005. Workforce Management Indonesia, Issue 3. New York: Literacy.

Sugiyono. 2012. Metode Penelitian Bisnis. Bandung: Alfabeta.

Suradinata, Ermata. 2002. Manajemen Sumber Daya Manusia, Suatu Tinjauan Wawasan Masa Depan. Bandung. CV. Ramadan.

Staw, Barry M. 1977. "Motivation in Organizations: Toward Synthesis and Redirection," dalam New Directions in Organizational Behavior, Barry M, Staw dan Gerald R,Salancik, ed. Chicago: St. Clair Press.

Sondang P. Siagian 1998, Manajemen Sumber Daya Manusia, Jakarta, Bumi Aksara.

Sondang P. Siagian, 2008, Manajemen Sumber Daya Manusia, Bumi Aksara.

Terry, George.R. dan Leslie W. Rue. 2003. Dasar-dasar Manajemen. Jakarta: Bumi Aksara.

Thoha, Miftah. 2007. Perilaku Organisasi Konsep Dasar dan Aplikasinya. Jakarta. Raja Grafindo Persada. 
Wirawan. 2009. Evaluasi Kinerja Sumber Daya Manusia; Teori, Aplikasi, dan Penelitian. Jakarta: Salemba empat.

Wheelen, Thomas L. dan J. David Hunger (2002). Strategic Management and Business Policy, Eighth Edition, New Jersey: Prentice-Hall.

Yamin, Martinis. dan Maisah. 2010. Standarisasi Kinerja Guru. Jakarta: Gaung Persada

Yukl, Gary. 2010. Leadership Organizations. Seventh Edition. New Jersey: Pearson.

\section{JURNAL NASIONAL}

AA, Fachri Husni., Jakarta, 2008, Pengaruh Kemampuan dan motivasi terhadap kinerja karyawan (studi kasus pada Bank Syariah Mandiri cabang Bogor)., Universitas Indonesia.

Analisis Pengaruh Motivasi dan Disiplin kerja terhadap kinerja karyawan PT Pundi Fajartama, Irene dan Nia Kurniaty, Binus University, Jakarta, DKI Jakarta Indonesia

Asih, Suci. Januari, 2007, Disiplin, Pelatihan, Motivasi, dan Kinerja Karyawan. PT. Refconindo Bintang Sejahtera. Universitas Indonesia Esa Unggul

Artana, I Ketut., Maret, 2006, Semarang, Analisis Kinerja Pegawai Balai Pengelolaan Sumber Daya Air Serayu Citanduy Dilihat dari sisi tingkat Kedisiplinan, Motivasi, dan Kemampuan Kerja Pegawai., Universitas Diponegoro.

Gayatri, Titan Erwina., Juli., 2011, Analisis motivasi, kemampuan kerja dan kinerja pegawai pusat pengelolaan komplek Gelora Bung Karno., Universitas Indonesia

Gusti, Messa Media., 2012, Yogyakarta, Pengaruh Kedisiplinan, Motivasi kerja, dan Persepsi Guru Tentang Kepemimpinan Kepala Sekolah Terhadap Kinerja Guru SMKN 1 Purworejo Pasca Sertifikasi., Universitas Negeri Yogyakarta.

Marjono 2007. Pengaruh kedisiplinan, motivasi dan fasilitas sekolah terhadap prestasi belajar siswa kelas VIII SMPN 8 Prworejo. Tesis Purwokerto: Program Pasca Sarjana Universitas Jendral Soedirman.

Mesra, Tien Danarti., Oktober., 2005. Analisis Hubungan antara Faktor Motivasi dan Kemampuan kerja dengan kinerja pegawai di bagian verifikasi dan 
Jurnal Riset Manajemen Sains Indonesia (JRMSI) | Vol 7, No. 1, 2016

akuntansi Biro Keuangan dan Perlengkapan Departemen Perindustrian dan Perdagangan., Universitas Indonesia.

Milanti, Rise., Juni, 2006, Pengaruh Faktor-faktor motivasi terhadap hasil penilaian Kinerja Sales Force di Dept. Sales \& Marketing PT. Danapaint Indonesia.,Universitas Indonesia.

Widyastuti, Endang Nur., 2004, Bandung, Analisis pengaruh iklim organisasi dan motivasi terhadap kinerja pegawai melalui variable intervening kepuasan kerja., Universitas Pendidikan Indonesia.

Jurnal Manajemen Bisnis Vol.1 No_1 Jan 2008 27-4-2012 2:45 PM, ISSN:19788339.

Performance Appraisal Pada BPRS Saparudin Siregar IAIN Medan Pembelajaran Organisasi: Strategi Membangun Kekuatan Perguruan Tinggi, Yeni abash Staf Pengajar FE USU

JBM Volume 4 No.2 Januari 2008. Jurnal Ilmiah Berkala Empat Bulanan, ISSN 1411_9366 Volume 4 No.2, Januari 2008

Pengaruh Stress Kerja Terhadap Kinerja Karyawan Redaksi Surat Kabar Harian Umum Lampung Post, Rosnelly Rusdi, Dian Septiani

\section{JURNAL INTERNASIONAL}

Benkhoff. (1997). "Ignoring Commitment Is Costly: New Approaches Establish the Missink Link Between Organizational Commitment and Performance," Human Relations, 50, (6).

Bishop, Scott \& Burroughs. (2000). "Support Commitment and Employee Outcomes in a Team Environment", Journal of Management, 26, (6).

Judge, e. al., Timothy A. (2001). "The job satisfaction-job performance relationship: a qualitative and quantitative review," Psychological Bulettin, Vol. 127 No. 3, 376-407.

Nikolaou, Ioannis. (2003). "Fitting the person to the organisation: examining the personality-job performance relationship from a new Perspective," Journal of Managerial Psychology, Vol. 18 No. 7, 2003, 639-648.

Petty, M. M., Mcgee, Gail W., dan Cavender, Jerry W. (1984) "A meta-analysis of the relationships between individual job satisfaction and individual performance," The Academy of Management Review, October, Vol. 9 No. 000004, ABI/INFORM Global, 712. 
Sanders, Sanders. (2008). "Using personality traits to predict police officer performance," Policing: An International Journal of Police Strategies \& Management, Vol. 31 No. 1, 129-147.

Sarmiento, Roberto dan Jo Beale. (2007). "Determinants of performance amongst shop-floor employees: a preliminary investigation," Management Research News, Vol. 30 No. 12, 915-927.

Shaw, Delery \& Abdulla. (2003). "Organizational Commitment and Performance Among Guest Workers and Citizens of An Arab Country," Journal of Business Research, 56.

Vaibhav Chawla \& Sridhar Guda (2010). Individual Spirituality at Work and Its Relationship with Job Satisfaction, Propensity to Leave and Job Commitment: An Exploratory Study among Sales Professionals. JOURNAL OF HUMAN VALUES 16:2 (2010): 157-167 DOI: $10.1177 / 097168581001600203$ 